\title{
The Meaning of Embroidery and 'Kelom Geulis' as a Business based on Local Wisdom
}

\author{
${ }^{1}$ SANTI SUSANTI, ${ }^{2}$ FITRI PERDANA, ${ }^{3}$ RACHMANIAR \\ 1,2,3Universitas Padjadjaran, Jl. Raya Bandung-Sumedang Km. 21, Indonesia \\ email: ${ }^{1}$ santi.susanti@unpad.ac.id; ${ }^{2}$ fitri.perdana@unpad.ac.id; ${ }^{3}$ rachmaniar01@gmail.com
}

\begin{abstract}
This research aims to reveal the construction of meaning of Tasikmalaya handicraft entrepreneurs in maintaining their existence in the midst of global competition today. The business of kelom geulis (beautiful wooden sandals) is the object of this study because it has functional value and there are many demands from buyers. Using qualitative with a phenomenological approach, research data is collected through direct observation, in-depth interviews with kelom geulis and bordir (embroidery) entrepreneurs, as well as documentation studies to complete the data gathered from the location. The result shows that the business of embroidery and kelom geulis is an effort to preserve local cultural heritage and identity of Tasikmalaya unique handicraft from extinction. This research concludes that Tasikmalaya City handicraft entrepreneurs interpreted the embroidery and kelom geulis business as an effort to fulfill life necessities and preserve the ancestor's heritage to maintain the identity of Tasikmalaya as handicraft center that has long been known.
\end{abstract}

Keywords: local culture, meaning, preservation.

\section{Introduction}

Tasikmalaya is known as the center of craft industries in West Java. Craft industry has become an income for most of Tasikmalaya people. It is well known domestically and has been exported to various countries, including Malaysia, Brunei, Saudi Arabia, Dubai, and the United States.

Even though it has been exported, the process in the making of handicrafts is still using human power in home industry scale. Craft production knowledge is obtained from parents, family, neighbors, or society.

In his research, Darusman (2016), explains that Tasikmalaya handicraft industry management is traditionally institutionalized. Production institution by reliable craftsmen, distribution institution by intercity and interregion traders, and marketing institution through a distribution center and local, national, inter-island markets and even exports abroad. This trading management is effective to elevate the economy of Tasikmalaya people and the products are as interesting as modern products by machine
(Darusman, 2016).

The creative industry is highly resistant to the global economy changes. When the world economic crisis happens, just like what happened back in 1997, the creative industry still survives from getting down. Florida believes that creativity is "a fundamental source of economic growth". It emerges the creation of new ideas, technologies, and creative content (Vesela \& Klimova, 2013).

The terms of creative economy were used for the first time in 2001 by John Howkins in his work "The Creative Economy: How People Make Money from Ideas". He was the first to highlight creativity as a driving force of economic growth. The developed world is aware of the importance of creativity, evidenced by the celebration of August 21 as World Creativity and Innovation Day since 2002 (Vesela \& Klimova, 2013).

Various innovations developed from the master product are able to maintain the survival of the creative industry, as happened in the Tasikmalaya embroidery and kelom geulis industry. The creativity 
that continues to be developed and the management of family-based industries which eliminates attachments in labor union organizations is able to make these significant products of Tasikmalaya last until recently. Knowledge of the production process and management of the industry that took place for generations allows the skills possessed by craftsmen to continue to be sustainable and maintain the stability of the inclusion of local wisdom in managing handicraft businesses in Tasikmalaya.

This research is focused on the construction of meaning of Tasikmalaya's embroidery and kelom geulis craftsmen in maintaining business based on local wisdom of the society in the midst of competition with products produced by machines. Embroidery and kelom geulis craftsmanship were chosen as the research object because of their aesthetic and function values they have at the same time and there are craft centers of these two products in Tasikmalaya City.

This research formulated into the main question of "How does the construction of meaning of Tasikmalaya embroidery and kelom geulis craftsmen in maintaining the existence of their business based on local wisdom?". The main questions are breaking down into: 1) How do the Tasikmalaya embroidery and kelom geulis entrepreneurs interpret their businesses to be maintained? 2) What is information literacy experience of Tasikmalaya embroidery and kelom geulis in getting knowledge of production and passing it down to the next generation?

Previous research on handicraft products as a featured commodity of Tasikmalaya society was done by Darusman (2016) from Universitas Siliwangi, entitled Local Wisdom of Tasikmalaya Embroidery as a Creative Economy Open to Modern. This qualitative research finds that embroidery is local wisdom in the form of a creative economy that is adaptive to the development of the times. It becomes a featured product that is able to elevate the economic growth of the Tasikmalaya society. Management of embroidery trade system by the family is running simultaneously with the transfer of knowledge and skills to the families and communities of artisans from generation to generation made it difficult to be imitated by the people outside Tasikmalaya.

This research is relevance in terms of subject and object, namely Tasikmalaya embroidery. However, my research was not done only to one object, but two, namely the embroidery and kelom geulis.

Another research of kelom geulis in Tasikmalaya City as a Complementary to Women's Fashion was conducted by Sofyan et al (2018). The results of this study indicate that kelom geulis made in Tasikmalaya City has a good quality, lovely look, and able to improve the appearance of any woman who use it. The quantity of production has increased due to many requests from inside and outside the country.

This research has the same object, namely kelom geulis. The difference with the previous research lies in the focus. If that study focuses on the role of kelom geulis as a complement to women's fashion, the research I conducted focuses on the meaning construction of embroidery and kelom geulis entrepreneurs in the business they run and maintained.

Added value is an important element of a creative economic product which can turn a normal product into more valuable than similar. It could create creative economic opportunities and attract many people.

Generally, humans will act on something (objects, events, and others) that has meaning for them. Meaning is formed through social interaction with others and one's interpretation of the aspects that he/she wants to give meaning to. It is influenced by the thinking process based on the stock of information they have (Blumer in Griffin, 2006: 56-59).

One's interpretation towards something can be known through social interaction. Speech and behavior is a reflection of someone's interpretation to something. The formation of meaning involves many factors, such as the environment, the developing system, and the capacity of individuals such as personal factors (Bajari, 2009: 7). A meaning is dynamic. It can change by time and the development of environment. These changes have implications for changing the system of values, beliefs, and attitudes toward something. This research explores the meaning of individual about the craft businesses they are carrying out. Each individual is unique, thus, the meaning of craft business they live with will be different according to the stimuli they get from the internal and external environment.

Traditional crafts have become part of life for the people of Tasikmalaya and are cultured as a form of local wisdom in order to 
overcome problems related to fulfilling their life needs. This is as stated by Fajarini (2014) that local wisdom is a view of life, science, and life strategies that form the activities of local people in fulfilling their daily needs.

Local wisdom which is also interpreted as traditional knowledge is a central element of the development process and the life of the local community. Traditional knowledge is a resource for local communities to develop. The continuity of traditional knowledge depends on its ability to adapt to modern life (Githui et al., 2015: 37).

The functions of local wisdom include developing human resources, culture, and science as well as conservation and preservation of natural resources (Aulia and Dharmawan, 2010). Through knowledge, the Tasikmalaya people succeeded in exploiting the potential of natural resources and local human resources to become crafts that have aesthetic and economic value.

The skill of making embroidery and kelom geulis is a form of knowledge to overcome problems originating and passed on from generation to generation by craftsmen in Tasikmalaya. The regeneration process that lasted for many years has made embroidery skills and kelom geulis known as Tasikmalaya's distinctive skills and has become one of the wisdom of local society in the East Priangan region.

The process of transferring knowledge and skills of embroidery and kelom geulis is part of information literacy; the ability to interpret information into useful knowledge in human life, including education, problemsolving or making decisions in work and education (Bruce, 2003). Literacy is needed in social interactions so that someone can actively support the group and society. Literacy is needed to make someone develop in the global world. Information literacy is also the basis for lifelong learning.

In this research context, literacy skills on information about the embroidery and kelom geulis which obtained through direct practice from generation to generation encourage entrepreneurs to find solutions relating to the supply of materials, production processes, and handicraft products so that the business can grow.

\section{Research Methodology}

This research employed qualitative phenomenology method to express the meaning of Tasikmalaya embroidery and kelom geulis entrepreneurs in managing local wisdom-based businesses.

Phenomenology identifies the human experience of certain phenomena. The goal is knowing someone's meaning of something from the point of view of people who experience it (Creswell, 2010:20; Bryman, 2016).

In conveying reality, according to Kuswarno, qualitative research is more relevant than quantitative. Because of that, phenomenology research does not aim to test the theory because theory uses as a tool. Observation, in-depth interviews, and document analysis are used to collect research data (Diniati, Nuraeni, \& Mahadian, 2015).

The results of the study are presented in the form of descriptive words data based on oral exposure and observed people's behavior (Bogdan and Taylor in Moleong, 2006: 4). Qualitative research data is data in the form of words, sentences, gestures, facial expressions, graphics, images, and photographs (Sugiyono, 2012).

The behavior of Tasikmalaya craftsmen in maintaining their business is depicted based on the informant's narrative through a phenomenological approach, that is a research approach which, according to Littlejohn "makes real experience a reality data base" (Abdi, Hafiar, \& Novianti, 2015).

The phenomenology approach was used to explore the meaning of embroidery and kelom geulis for craftsmen in Tasikmalaya City in the current era of global competition. The research sample was chosen based on purposive sampling. A number of criteria are established to obtain research samples in accordance with the research objectives (Kriyantoro in Mala, 2016). The criteria used to choose the informants were 1 ) residents of Tasikmalaya City, who 2) owned embroidery business and kelom geulis, 3) willing to be interviewed, and 4) could express their experiences verbally.

The snowball technique is also used to obtain information about other informants from the informants interviewed. This procedure is taken to ensure that the informants are relevant to research problems. (Bungin, 2011: 107).

Through these processes, 17 individuals were willing to express their experiences 
in maintaining the embroidery and kelom geulis business consists of 10 embroidery craftsmen and 7 crafters of kelom geulis. The crafters of kelom geulis are concentrated in the area of Jalan Tamansari Gobras, while the embroidery entrepreneurs are scattered in various areas in Tasikmalaya City with the center of craftsmen in Kawalu District.

In this study, the main data were obtained through interviews to the embroidery crafts and kelom geulis that still survive in the midst of competition with modern products, as well as observing the behavior of informants when they were being interviewed and the situation at the production site and showroom /embroidery shop and kelom geulis. Secondary data is obtained from newspapers, journals, websites, as well as written docum ents relating to embroidery craft and kelom geulis in Tasikmalaya City.

Data were analyzed inductively with interactive data analysis techniques of Miles and Huberman. The process includes data reduction, data presentation, and conclusions. This process continues until conclusions are drawn which cover the essence of the study.

This study uses phenomenology theory to explain the meaning construction of Tasikmalaya's embroidery crafts and kelom geulis to main tain the continuity of their business. How knowledge of production and marketing is transmitted and how that knowledge is implemented; and how local wisdom in the products produced adapts to modern marketing systems. The meaning of a person towards a phenomenon is constructed based on the presentation of the perspective of the person who experiences it. (Polkinghorne in Creswell, 2010: 51; Kuswarno, 2009).

The Social Action Theory from Max Weber was applied in this study to describe the interaction of informants with the surrounding environment in maintaining their efforts. According to Weber, social action is all individual behavior that has a subjective meaning for itself and is directed towards the actions of others (Weber in Ritzer, 1975). Actions can be open or hidden, can be a positive intervention in a situation or deliberately silent as a sign of agreement in the situation.

Every human behavior is carried out based on certain motives to achieve, both to the other person and himself according to the purpose of communication.

\section{Results And Discussion \\ Embroidery in Tasikmalaya}

According to Indonesia Dictionary (Departemen Pendidikan Nasional, 2008), embroidery is an ornament of yarn threaded on cloth. At first, the tool used for embroidery was an ordinary sewing machine that was moved by foot, which among craftsmen was known as the kejek machine.

This model of the sewing machine is known as the Juki machine or Juki brand sewing machine, which is estimated to begin entering Indonesia around 1920 after a visit from Japan and provide assistance in the form of Juki brand sewing machine. Along with the development of technology, Juki machines were eliminated by embroidery machines using computer technology that was more economical and efficient because they were able to produce far more with the same quality.

The Tasikmalaya embroidery industry began to grow and develop in 1925 in Tanjung Village, Kawalu District, Tasikmalaya City. The business was initiated by $\mathrm{Hj}$. Umayah binti $\mathrm{H}$. Musa, who had worked at an American embroidery company, Singer. After mastering embroidery skills while working at Singer, she left and returned to Tanjung Village and opened a small business by receiving embroidery or der from Tasikmalaya and outside the region. Seeing promising business prospects, then $\mathrm{Hj}$. Umayah shared her knowledge of embroidery by training her family, neighbors, and close relatives in an embroidery business.

After $\mathrm{Hj}$. Umayah passed away, the business was continued by her family, including $\mathrm{H}$. Rosyad, H. Sarbeni, H. Sarhasih and $\mathrm{H}$. Zarkasy. From there, the embroidery business developed rapidly not only in Tanjung Village, Kawalu District, but also spread to other areas, such as Sukaraja District, Tanjungjaya, Singaparna, Sukarame, Cibalong, Cikatomas and other regions.

In 1955, craftsmen tried only to meet the needs of the local market around Tasikmalaya and Ciamis, but after a conflict between residents and DI/TII which forced the Tasikmalayan youth to become Islamic soldiers, many of them escaped to Jakarta. In order to survive, they sold their embroidery skills product to Chinese entrepreneurs in Jakarta. They are H. Rosyad, H. Zarkasy and H. Sarhasih. 
After DI / TII surrendered to the Indonesian Armed Forces in 1966, the situation in Tasikmalaya was back in safe. The young men in Jakarta returned to Tasikmalaya with orders for embroidery from Chinese entrepreneurs in Jakarta. Since then, embroidery production has been strived on a large scale by the community with labor-intensive models. The produce was accommodated by CV Kernasio, the people's economic institution formed by $\mathrm{H}$. Rosyad and his friends.

\section{The Process of Spreading Embroidery Skills}

Embroidery is a traditional handicrafts that become the featured product of Tasikmalaya. Tasikmalaya embroidery is absorption from Chinese culture, which is adapted into Indonesian clothing and accessories with local flavors. There is a variety of clothing decorated with attractive embroidery. The typical motif of Tasikmalaya embroidery is floral motifs that are applied to veils, kebaya (Indonesian traditional clothes/ brocade fabric), mukena (Moslem prayer clothes for women), tunics, scarves, skirts, bed sheets, pillowcases, tablecloths, robes, koko clothes, hajj caps, and daily wear.

Embroidery skills are expanding to almost all residents of the city and Tasikmalaya Regency in an informal way; through informal education in families, neighbors, craft entrepreneurs, and craftsmen. There are no formal educational institutions that practice embroidery skills. There was once a Craft Industry Institute/ Lembaga Industri Kerajinan (LIK) formed by the government but it failed because the skills acquired through LIK did not match the skills needed by users or embroidery confectioners. Craft entrepreneurs prefer to train their own employees according to production needs that are in demand by the market.

Good quality with relatively affordable prices make Tasikmalaya embroidery acceptable to the community so that its market share expands. Tasikmalaya embroidery products have been marketed overseas. Domestic marketing includes Bandung, Cirebon, Surabaya, Bali, Manado, Makassar, Batam, Pontianak, and others. Foreign markets are Malaysia, Singapore, Africa, Egypt, Middle East countries, and others (Tasikmalaya City Industry and Trade Service, 2014). Especially in the country, the City of Tasikmalaya helps marketing the embroidery products by providing a special place, that is Pusat Penjualan Bordir Khas Tasikmalaya (Tasikmalayan Embroidery Sales Center) in Pasar Tanah Abang, Jakarta.

The dynamics of embroidery business have often been experienced by the Tasikmalaya craftsmen society. There is a period of switching to a capitalist institutional model where craftsmen work in several entrepreneurs in big cities such as in Jakarta, Yogyakarta, Tulung Agung, and Solo. They get a capitalist company model wage with monthly payments. It turned out that it did not last long; the craftsmen returned to Tasikmalaya because the model of the capitalist trade system did not open opportunities for craft workers to become proficient craftsmen or entrepreneurs. They will forever remain laborers in embroidery. It is very different from the trade system model in Tasikmalaya where a craft worker can turn into a maklooner (contract manufacturing) and become a young entrepreneur because the relationship between the employer and the patron-client pattern is mutually beneficial and encouraging each other. All major businessmen of embroidery operations come from unskilled laborers, then become skilled and proficient laborers, and then can become independent entrepreneurs.

Based on the process, embroidery craftsmen in the City of Tasikmalaya consist of three categories, namely manual embroidery craftsmen who still use traditional sewing machines or cruel machines in the process of producing embroidery. The amount of production produced is not much because the production process to produce one embroidery product is the fastest three days to one week of work. The dominance of human power is in the work of manual embroidery, while automatic embroidery craftsmen use computer embroidery machines. One machine can produce up to 12 appliques at once. Human power is needed as a machine operator. Applique is done by the machine after the embroidery design is inserted into the embroidery machine computer. Machine engraving is generally applied to bags, koko clothes, mukena, etc.

There are significant differences in the two types of craftsmen, especially in the quantity of production produced. Craftsmen who use computer sewing machines produce more embroidery production than those using traditional sewing machines. Its nature is bulk and the selling price is cheaper than 
the selling price of embroidery products that are sewn using traditional sewing machines through human power.

\section{Kelom Geulis}

Kelom geulis is a wooden sandal produced in Tasikmalaya and given decoration to make it look "beautiful." In ancient times, kelom geulis was one of the footwear types favored by residents of Tasikmalaya and its surroundings, and was one of the handicrafts that had a function and aesthetic value at the same time.

The word kelom geulis is a combination of two words, namely kelom and geulis. Kelom means footwear made from wood, clogs; wooden sandals for women. The word geulis comes from Sundanese which means beautiful. If the two are combined, it will be a kelom geulis which means beautiful/lovely wooden sandals. The display of wooden footwear is decorated with colorful paint and interesting motif carvings on the body of the kelom. It is said that at that time, women who wore footwear would look beautiful, graceful, and charming. (Somantri, 2015).

Kelom geulis is made of mahogany or Albasia which is made manually by hand. In order to look more aesthetic and attractive, kelom geulis is equipped with decorations that use carvings or drawn directly on the clom section using a brush or airbrush technique. Motives that are often used in carvings and paintings in kelom are floral or batik ornaments. For coloring, it uses a brush or an airbrush technique. The carved application on the kelom geulis is formed with firm lines, which are generally in the form of floral motifs or given batik decorations so that the term kelom batik is known.

Kelom geulis usually uses by women, ranging from teenagers to parents for certain formal events, such as celebrations, weddings, and so on.

Kelom geulis is one of the consumptive items that can be used as a complementary fashion to add to the aesthetic appeal of the wearer. Through this role, kelom geulis are still in demand and used by most local people, especially in Tatar Pasundan (Sundanese land).

Kelom geulis was designated as the 2016 Indonesian Intangible Cultural Heritage by the Ministry of Education and Culture of the Republic of Indonesia (Pikiran-rakyat.com, 2016). As the consequences, the Tasikmalaya regional government and its people, especially the craftsmen, have a moral obligation to maintain the existence of kelom geulis so that they do not become extinct.

Data from Dewan Kerajinan Nasional Daerah Tasikmalaya/The National Craft Council of Tasikmalaya (Dekranasda) as well as the Tasikmalaya City Department of Cooperatives, MSMEs, Industry and Trade in 2014 showed that the kelom geulis industry in Tasikmalaya consisted of 504 business units, 5,924 workers, an investment value of Rp 135.25 billion, and a production value of Rp 396 , 27 billion (Sedayu, 2014).

As a fashion product, kelom geulis must be able to adjust to changing modes in order to support the lifestyle of its supporting society. Therefore, creativity is needed to produce innovations on kelom geulis model so that the development of fashion is updated and capable of continuing the production.

Many kelom geulis crafts produced as a home industry in Tasikmalaya City and Regency. One of the centers of kelom geulis in Tasikmalaya City is in Tamansari District area. Almost along the street of Tamansari Gobras, you can easily find kelom geulis stores that offer a variety of diverse designs to buy. Not far from the store, there is usually a kelom manufacturing factory owned by a shop owner.

The craft of kelom geulis was pioneered between 1940 and 1950 in the Gobras area. Previously, the Gobras community had skills to make wooden footwear in the form of clogs and gamparan. Clogs are wooden sandals that are given a black tie on the top, while gamparan are wooden footwear with lilac on top, namely the top of the gamparan which is pinched by the second toe and toes. Gamparan is usually used by men (Somantri, 2015).

In her writing, Ria Andayani Somantri (2015) explained that during the 1940-1950 period, there was a Gobras resident named Pohir or Ohir who worked as a laborer in a sandal production site in Bandung. At one time, Ohir wanted to make wooden sandals. Together with three of his friends at Gobras, Ohir succeeded in making his wish come true by making raw clogs that were not ready to use because there was no face or top. At that time, they had not been able to make the top of kelom geulis. The product was then taken to Bandung for sale and turned out to sell well. They also received orders for raw 
kelom from Bandung with a new model, which was given carved ornaments. The carving motifs on kelom geulis are mostly inspired by the surrounding environment, such as floral motifs. The results of their creations are favored by consumers. The marketing of the kelom geulis extends from Bandung to Jakarta. The number of craftsmen continues to grow and they are able to complete the top of kelom geulis until they are ready to use.

Kelom geulis was very popular as a complement to women's clothing at that time. The glorious day of kelom geulis slowly faded with the entry of factory-made sandals. The peak of destruction occurred in the 1970s when there was only one craftsman survived, namely Husen. The handicraft business of the kelom geulis stretched back in 1979 when one of Gobras resident succeeded in creating kelom from plywood sheets. These products are favored by domestic and foreign consumers. Finally, kelom geulis has survived until now. Tasikmalaya kelom geulis has been exported to Southeast Asia, Japan, Korea, Africa, Panama, the Middle East, and parts of Europe.

The attractive part of kelom geulis lies in the decoration on the surface or on the sides of the sandals. Ornament of kelom geulis takes flower motifs such as roses, orchids, jasmine, sun, and even bird images and children's cartoon characters are also often used as decoration on kelom geulis. In general, decoration on kelom geulis is done by using techniques or drawn directly on the kelom using a brush or by airbrush. There are even those who are made by using night wax materials that are commonly used for batik.

The working process of kelom geulis is still done manually using human power (handmade). The production machine is used as a tool for making kelom, such as for punching kelom rights or for sanding. To produce one pair of kelom, the process carried out is quite long. There are more than 8 stages that must be passed since the material is still in the form of wood; it is cut, formed, sanded, cured, dried in the sun, and carved to form a pair of kelom geulis. The process is done collectively by workers who have different skills because in the kelom industry it has been patterned if one part of the work is only done by one person. Thus, everyone has their own expertise in working on the parts of the kelom geulis. There are those who have the expertise to put up soles, sand up, carve, decorate clogs, and so on.
The process is not fully done at the factory, but there is a separate division. For example, cutting until the drying process is done in the factory, while the installation of the rope is done by the craftsmen home.

The process of learning the skills of craftsmen is generally carried out independently from generation to generation through informal education or direct practice carried out through families, neighbors, and ustadz (religious teacher) who master the skills of making the kelom geulis. (Darusman dkk., 2019). This is in accordance with the statement in the National Education System No. 20 of 2003 article 27 which states that "Informal education activities carried out by families and the environment take the form of independent learning activities".

\section{The Meaning of Embroidery Craft and "Kelom Geulis"}

Construction of meaning is an individual process of understanding something and conveying it to others as part of daily social processes. The construction of meaning by individuals involves many factors, such as the environment, the developing system, and the capacity of individuals such as individual personal factors (Bajari, 2009).

According to Blumer (in Griffin, 2006: 56-59), the meaning of a person towards others or something is influenced by the social interaction they do and the thought process based on the content of information and experience that has the symbol/someone who is given that meaning. The meaning that appears is the basis for acting on someone or something that is given that meaning. Thus, each individual will produce different meanings for the same object according to the thinking process he/she does.

Informants of this research interpret the craft business they pursue based on thinking process with experience and knowledge about crafts as their processed material. Based on the stimuli they get from the environment, such as events and situations that develop, each individual embodies the meaning of embroidery and kelom geulis differently into various forms of work that can be seen and enjoyed by the results. These works are realized according to their personal interests and abilities. The more diverse the meaning is, the more diverse the results of the work would be.

For the embroidery craftsmen and 
kelom geulis, the culture in their neighborhood influences the perspective on embroidery and kelom geulis they are engaged in. As entrepreneurs, there are certain meanings inherent in them related to the embroidery and kelom geulis.

For Eming Muhaimin (34), engaging in kelom geulis business is his effort to utilize the potential of Tasikmalaya region in raw materials and human resources. He also has mastered the production process, can be seen in the figure 1 . Thus, there is pride in pursuing kelom geulis business.

"There's a proud in me. In addition to producing rupiah, I also preserve the inheritance from ancestors. It becomes culture that generates money." (Eming interview, April 22, 2018)

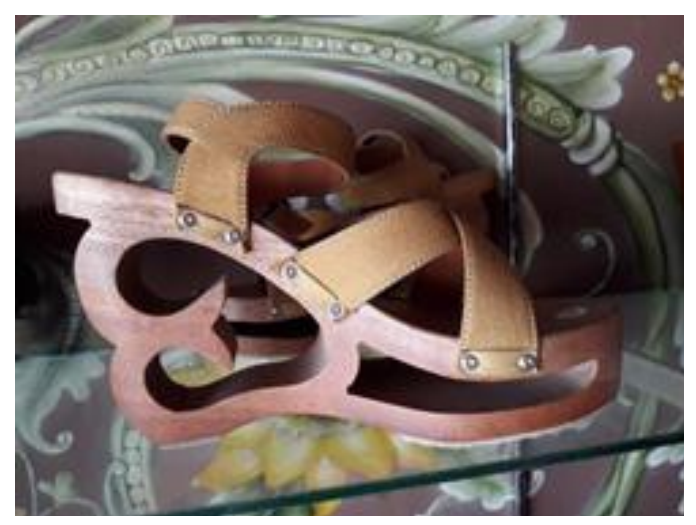

Figure 1. One of the kelom geulis produced by Eming with the brand Karima Key.

(source: research documentation)

For Ida (51), the owner of Mustika Kelom, the business of kelom geulis she run was a legacy from her parents who had pioneered their business since 1964. However, at that time, they did not have a shop like now. Kelom is sold around the nearby area. The shop was established in 1983, a year after Ida got married.Ida interpreted her kelom geulis business as a livelihood that will be maintained in any condition.

Meanwhile, Hj. Nazmia (56) owner of Mia Bordir, as can be seen in the figure 2, said that the embroidery business she practiced was part of worship to Allah Subhanahuwataa'la in fulfilling the needs of people who want to wear clothes with beautiful applique, while lifting embroidery as the work of quality of the Indonesian people.

"Tasik is famous for its embroidery. Surely, good work makes people recognise, oh this is fromTasik. It can be sold overseas, so that we can connect ourselves to the work of
Indonesian people." (Nazmia interview, July $16,2018)$

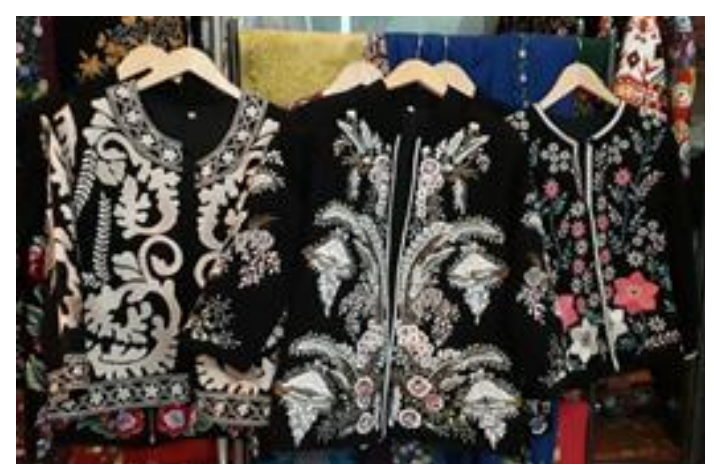

Figure 2. Embroidered blazer, a collection of Mia Bordir made with a manual sewing machine

(source: research documentation)

In order to meet these needs, the manufacturing process is also carried out using a manual sewing machine by skilled embroidery tailors.

"I'm not made a mass product. I mean my capacity is not much. With such capacity, I really pay attention to the quality. Of course, people will search for a good quality product. I am not a market segment person who goes everywhere." (Nazmia interview, July 16, 2018)

The same thing was expressed by Iman (42), the manager of Ariesta Bordir. The business managed by his mother was interpreted as an effort to raise the name of the City of Tasikmalaya as a city of embroidery crafts.

\begin{abstract}
"Uplifting Tasik City, of course. When you see embroidery, it's sure, 'oh it must be from Tasik'. That's, it, nothing else. Firstly, nationalism in Tasik City is elevated; secondly, the government is proud of SMEs for marketing their products overseas. "(Iman interview, April 21, 2018)
\end{abstract}

For Tuti (47), the owner of Raisa Bordir, the embroidery business that she practiced was interpreted as an expression of soul and feeling. This is related to the creative side that Tuti poured in the design of Raisa Bordir, especially in choosing colors, which according to Tuti, brought its creator's characters.

"The number of full colors illustrates the firmness of the color, the purple-blue- green, that's obvious in this way and that's my result. As for the pastel colors of green, the colorful ones are the result of the character of my child and my child that makes the color palette. I cannot force my child to color the embroidery with my character, so he color it with his own character " (Tuti interview, May 8, 2018) 


\section{Conclusions}

Tasikmalaya City handicraft entrepreneurs interpreted the embroidery and kelom geulis business as economic and cultural efforts. In addition to fulfilling life necessities, the craftsmen went about their business as an effort to preserve the heritage of their ancestors and to maintain the identity of Tasikmalaya as the center of handicrafts that have been known for a long time.

Passing on the expertise to the next generation is one effort to maintain the embroidery and kelom geulis from becoming extinct. The local government must also be more active in approaching the craftsmen, so the marketing of embroidery and kelom geulis products can be more optimized.

\section{References}

Abdi, F. F., Hafiar, H., \& Novianti, E. (2015). Perilaku Komunikasi Etnis Tionghoa Peranakan dalam Bisnis Keluarga. Jurnal Komunikasi, 9(2), 105-118. http:// dx.doi.org/10.21107/ilkom.v9i2.1190. Retrieved March 24, 2019 from http:// journal.trunojoyo.ac.id/komunikasi/ article/view/1190/1012

Aulia, T.O.S., Dharmawan, A.H.(2010). Kearifan Lokal dalam Pengelolaan Sumberdaya Air di Kampung Kuta. Sodality: Jurnal Transdisiplin Sosiologi, Komunikasi dan Ekologi Manusia, 4(3): 345-355.

Bajari, A. (2009). Konstruksi Makna dan Perilaku Komunikasi pada Anak Jalanan di Cirebon: Studi Fenomenologi pada Anak Pengamen Kota dan Anak Pengemis di Lingkungan Makam Sunan Gunung Jati Cirebon, Disertasi, Pascasarjana Universitas Padjadjaran.

Bruce, C. (2003). The Seven Faces of Information Literacy. Adelaide: Auslib Press.

Bryman, A. (2016). Social Research Methods. New York: Oxford University Press.

Bungin, M.B. (2011). Penelitian Kualitatif. Jakarta: Kencana Prenada.

Creswell, J. W. (2010). Research Design: Pendekatan Kualitatif, Kuantitaif, dan Mixed. Yogyakarta: Pustaka Pelajar.

Darusman, Y. (2016). Kearifan Lokal Kerajinan Bordir Tasikmalaya sebagai Ekonomi Kreatif Terbuka untuk Modern (Studi di Kota Tasikmalaya Jawa Barat). Journal of Nonformal Education, 2(2). https://doi. org/10.15294/jne.v2i2.6556. Retrieved
March 22, 2019 from https://journal. unnes.ac.id/nju/index.php/jne/article/ view/6556/5187

Darusman, Y., Mumu, Mustakim, Herwina, W. (2019). Model Pewarisan Budaya melalui Pendidikan Informal (Pendidikan Tradisional) pada Masyarakat Pengrajin Kayu. Wacana Akademika, 3(1): 95-108. http://jurnal.ustjogja.ac.id/index.php/ wacanaakademika/article/view/4034

Departemen Pendidikan Nasional. (2008). Kamus Besar Bahasa Indonesia Edisi Keempat. Jakarta: Gramedia Pustaka Utama.

Diniati, A., Nuraeni, R., \& Mahadian, A. B. (2015). Makna Konsep Diri Mantan Anak Jalanan. Jurnal Kajian Komunikasi, 3(1), 41-47. https://doi.org/10.24198/jkk. v3i1.7392

Fajarini, U.(2014). Peranan Kearifan Lokal dalam Pendidikan Karakter. Sosio Didaktika 1(2): 123-130.

Githui, W., David, N., and Maurice, S. (2015). The Role of Indigenous Knowledge in SocioEconomic Development. International Journal of Science and Research (IJSR), 4(4) April: 32-37. [online) at https://www. ijsr.net/archive/v4i4/16111405.pdf.

Griffin, E. (2006). A First Look at Communication Theory. New York: McGraw-Hill Inc.

Ida. (2018, May 16). Personal interview.

Kuswarno, E, (2009). Metodologi Penelitian Komunikasi Fenomenologi, Konsepsi dan Contoh Penelitian. Bandung:Widya Padjadjaran.

Mala, P.A. (2016). Manajemen Kesan melalui Foto Selfie dalam Facebook: Studi Fenomenologi pada Mahasiswa Ilmu Komunikasi UMS. Komuniti VIII(1), Maret: 47-52. https://doi.org/10.23917/ komuniti.v8i1.2933. Retrieved April 22, 2019, from http://journals.ums. ac.id/index.php/komuniti/article/ view/2933/1873.

Moleong, L. J. (2006). Metodologi Penelitian Kualitatif. Bandung: Remaja Rosdakarya.

Muhaimin, Eming. (2018, April 22). Personal interview.

Nazmia. (2018, July 16). Personal interview.

Puspitasari, S.N. (2016, October 22). Pemda Harus Serius Lestarikan Warisan Budaya. Retrieved from https://www. pikiran-rakyat.com/nasional/2016/10/28/ pemda-harus-serius-lestarikan-warisanbudaya-383369

Ramdhani, Iman. (2018, April 21). Personal interview.

Ritzer, G. (1975). Sociology: A Multiple Paradigm Science. Boston: Allyn and 
Bacon.

Sedayu, G. (2014). Industri Kreatif Tasikmalaya. Retrieved June 9, 2018, from https://galihsedayu.com/tag/industrikreatif-tasikmalaya/

Sofyan, A.N., Sofianto, K., Sutirman, M., dan Suganda, D. (2018). Seni Kerajinan Kelom Geulis di Kota Tasikmalaya sebagai Pelengkap Fashion Wanita. Sosiohumaniora, Jurnal IImu Sosial dan Humaniora, 20(2), Juli: 132-137.

Somantri, R.A. (2015). Sistem Ekonomi Pengrajin Kelom Geulis di Gobras, Kota Tasikmalaya, Provinsi Jawa Barat. Patanjala, 7(3), September: 477-492.
Retrieved March 22, 2019 from http:// ejurnalpatanjala.kemdikbud.go.id/ patanjala/index.php/patanjala/article/ view/113/66.

Sugiyono. (2012). Metode Penelitian Kuantitatif, Kualitatif dan $R \& D$. Bandung: Alfabeta.

Tuti. (2018, May 8). Personal interview.

Vesela, D., Klimova, K. (2013). Knowledgebased Economy vs. Creative Economy. Procedia-Social and Behavioral Sciences, 141: 413-417.

https://core.ac.uk/download/pdf/82367378. pdf 